\title{
Accumulation and toxic effects of chromium and zinc in Iris pseudacorus $\mathbf{L}$.
}

\author{
C. Caldelas · J. L. Araus • A. Febrero · J. Bort
}

Received: 23 August 2010/Revised: 30 January 2012/Accepted: 3 February 2012/Published online: 15 February 2012

(C) Franciszek Górski Institute of Plant Physiology, Polish Academy of Sciences, Kraków 2012

\begin{abstract}
The aim of the present study was to examine the ability of I. pseudacorus L., an ornamental macrophyte of great potential for phytoremediation, to tolerate and accumulate $\mathrm{Cr}$ and $\mathrm{Zn}$. Plants were grown in nutritive solution with $\mathrm{ZnCl}_{2}$ or $\mathrm{CrCl}_{3} \cdot 6 \mathrm{H}_{2} \mathrm{O}$ at $0,10,50,100$, and $200 \mu \mathrm{g} \mathrm{ml}^{-1}$ for 5 weeks; all survived and continued growing. The accumulation of $\mathrm{Cr}$ and $\mathrm{Zn}$ increased with increasing supply in all plant tissues, to reach $59.97 \mathrm{mg} \mathrm{Cr}$ and $25.64 \mathrm{mg} \mathrm{Zn}$ in roots. Leaves retained a remarkable amount of $\mathrm{Zn}(14.2 \mathrm{mg})$. Growth inhibition reached $65 \%$ and $31 \%$ (dry weight) in response to $\mathrm{Cr}$ and $\mathrm{Zn}$, respectively. The root:shoot dry matter partitioning $(R / S)$ increased $80 \%$ at $100 \mu \mathrm{g} \mathrm{ml}^{-1} \mathrm{CrCl}_{3}$. The most marked alterations in mineral content were in roots, where both metals decreased $\mathrm{Al}, \mathrm{Ca}, \mathrm{Mg}, \mathrm{Mn}$ and $\mathrm{S}$, and increased $\mathrm{P}$ concentration. No effect was noted on either leaf chlorophyll fluorescence kinetics $\left(F_{v} / F_{m}\right.$ and $\left.\Phi_{\mathrm{PSII}}\right)$, or photosynthetic pigment content, signifying that the light phase of photosynthesis was not impaired. Carbon isotope composition $\left(\delta^{13} \mathrm{C}\right)$ was only slightly heavier, indicating that the reduction of carbon fixation was not the main cause for growth decrease. This was attributed to the restricted mineral uptake and to the increased demand of carbohydrates of damaged roots. Biomass allocation to rhizomes $(\mathrm{Cr})$ or roots $(\mathrm{Zn})$ contributes to heavy metal tolerance by limiting transpiration and increasing metal-storing tissues and the surface for water and cation uptake. This
\end{abstract}

Communicated by K. Strzalka.

C. Caldelas $(\varangle)$ J. L. Araus · A. Febrero - J. Bort

Unit of Plant Physiology, Department of Plant Biology,

Faculty of Biology, University of Barcelona,

Diagonal 645, 08028 Barcelona, Spain

e-mail: criscaldelas@ub.edu species is a good candidate for $\mathrm{Cr}$ rhizofiltration and $\mathrm{Zn}$ phytoextraction.

Keywords Heavy metal - Abiotic stress - Toxicity · Phytoremediation $\cdot$ Macrophyte $\cdot$ Isotope

\section{Introduction}

Fresh water resources have been steadily reduced in recent decades as a result of increasing human consumption, contamination, and climatic change. Anthropogenic pollution of water is currently a major environmental concern as it poses a serious hazard for humans and other organisms, and dramatically limits the uses of water. Among the toxic substances found in water bodies, heavy metals deserve special attention. They are highly toxic at low doses, strongly persistent in the environment and living tissues, and easily transferred to food chain. In addition, their monitoring and removal is costly. $\mathrm{Cr}$ and $\mathrm{Zn}$, two of the most relevant heavy metals, are included in the US Environmental Protection Agency list of priority pollutants (USEPA 2005). Symptoms of $\mathrm{Cr}$ and $\mathrm{Zn}$ phytotoxicity include chlorosis, inhibited germination, stunted growth, reduced leaf number and area, reduced yield and flower production, inhibited photosynthesis, dysfunction of relevant enzymes, impaired nutrient uptake, plant wilting and altered water relations (Deng et al. 2006; Dhir et al. 2008; Prasad 2004; Shanker et al. 2005). The excess of metals has deleterious effects on the content and functionality of the photosynthetic pigments (Broadley et al. 2007; Shanker et al. 2005). This can be caused by the inhibition of the pigment synthesis (Prasad and Prasad 1987), the formation of metal-substituted chlorophylls of reduced functionality (Küpper et al. 1996), or the direct oxidative damage of the 
pigments (Oláh et al. 2010). Several authors have reported damages on the reaction centres or the peripheral antennae complexes of PSII in response to high concentrations of metals (Janik et al. 2010; Vernay et al. 2007; Paiva et al. 2009). Todeschini et al. (2011) recently described the reduction of D1 and D2 expression in poplar exposed to high levels of $\mathrm{Zn}$.

The phytoremediation of heavy metals by means of constructed wetlands constitutes a low cost, environmentally friendly alternative to conventional cleanup techniques (Salt et al. 1998). Furthermore, as metals accumulate mainly in roots, part of the biomass harvested from such wetlands has many potential uses in non-food industries. Some of these side-products that could yield substantial economic benefits for affected communities are biogas and compost (Malik 2007), fibres (Kuzovkina and Quigley 2005), and ornamental plants (Belmont and Metcalfe 2003). At present, few plant species with ornamental flowers have been evaluated for heavy metal removal in spite of their high market value. Several studies have revealed that Iris lactea var. chinensis (Fisch.) Koidz. Rank accumulates Cd in leaves and roots (Han et al. 2007), and Lythrum salicaria L. tolerates $\mathrm{Pb}$ (Uveges et al. 2002). However, greater research efforts are required to screen the performance of other suitable species.

Iris pseudacorus L. is native to Northern Africa, Western Asia and Europe, naturalized in Australia, New Zealand and North and South America, and cultivated worldwide as an ornamental plant. This plant displays a high rate of biomass production, tolerates polluted environments and is useful for water treatment purposes. Compared with Acorus gramineus Sol. in Aiton, Acorus calamus L., L. salicaria and Reineckea carnea (Andrews) Kunth, I. pseudacorus shows better performance in removing total nitrogen and phosphorus, $\mathrm{COD}, \mathrm{BOD}$, and heavy metals $(\mathrm{Cr}, \mathrm{Pb}, \mathrm{Cd}, \mathrm{Fe}, \mathrm{Cu}$, and $\mathrm{Mn})$ from sewage. In addition, it shows a high stress-tolerance response, which includes low lipid peroxidation, and increased proline levels and catalase activity (Zhang et al. 2007). I. pseudacorus plants exposed to high levels of $\mathrm{Cd}$ or $\mathrm{Pb}$ show decreased growth and chlorophyll content (Zhou et al. 2010), increased peroxidase, catalase, superoxide dismutase, and ascorbate peroxidase activity, and increased concentration of proline and malondialdehyde (Qiu and Huang 2008; Zhou et al. 2010). The roots are also able to form $\mathrm{Cu}$ nanoparticles in response to high levels of $\mathrm{Cu}$ (Manceau et al. 2008). I. pseudacorus shows a higher phenol concentration in roots than Phragmites australis (Cav.) Trin. ex Steud. and Typha latifolia L, which makes it more suitable for the treatment of metal polluted waters (Larue et al. 2010). However, there is insufficient information about heavy metal accumulation and distribution in I. pseudacorus and the effects of other metals on the parameters that condition biomass production, such as growth, chlorophyll synthesis, photosynthetic performance and plant nutritional status. These data are determinants in establishing the potential of this promising species for phytoremediation purposes. Here we assessed the physiological response of I. pseudacorus to a range of $\mathrm{Cr}$ or $\mathrm{Zn}$ concentrations, and evaluated the accumulation of these metals throughout the plant.

\section{Materials and methods}

Plant material and treatments

Iris pseudacorus L. plants were purchased from a local nursery (Bioriza, Breda, Spain) in 300-ml multipot containers holding a peat-perlite 50/50 substrate. Plants were then root-washed in tap water to remove the original substrate, weighed, and placed in a pure hydroponics system in individual 4-L pots containing diluted Hoagland nutritive solution at $\mathrm{pH}$ 6.5. This solution comprised $130.25 \mathrm{mg} \mathrm{l}^{-1}$ $\mathrm{NO}^{3-}, 5.5 \mathrm{mg} \mathrm{l}^{-1} \mathrm{NH}^{4+}, 28.5 \mathrm{mg} \mathrm{l}^{-1} \mathrm{PO}_{4}{ }^{2-}, 35.5 \mathrm{mg} \mathrm{l}^{-1}$ $\mathrm{K}^{+}, 24.5 \mathrm{mg} \mathrm{l}^{-1} \mathrm{Ca}^{2+}, 4 \mathrm{mg} \mathrm{l}^{-1} \mathrm{Mg}^{2+}, 14.25 \mathrm{mg} \mathrm{l}^{-1} \mathrm{SO}_{4}{ }^{2-}$, $0.325 \mathrm{mg} \mathrm{l}^{-1} \mathrm{Fe}, \quad 0.240 \mathrm{mg} \mathrm{l}^{-1} \mathrm{Mn}, 0.09 \mathrm{mg} \mathrm{l}^{-1} \mathrm{Zn}$, $0.030 \mathrm{mg} \mathrm{l}^{-1} \mathrm{~B}, 0.090 \mathrm{mg} \mathrm{l}^{-1} \mathrm{Cu}, 0.028 \mathrm{mg} \mathrm{l}^{-1} \mathrm{Mo}$, and $0.005 \mathrm{mg} \mathrm{l}^{-1} \mathrm{Co}$. After an acclimation period of 2 weeks, individual plants were selected within a small range of initial fresh weight $(104.0 \pm 5.2 \mathrm{~g}$ expressed as average \pm standard error). The nutritive solution was then amended with $\mathrm{ZnCl}_{2}$ or $\mathrm{CrCl}_{3} \cdot 6 \mathrm{H}_{2} \mathrm{O}$ at $0,10,50,100$, and $200 \mu \mathrm{g} \mathrm{ml}^{-1}$, which correspond to $\mathrm{Zn}$ ion concentrations of $0.07,0.4,0.7$ and $1.5 \mathrm{mM}$, and to $\mathrm{Cr}$ ion concentrations of $0.04,0.2,0.4$, and $0.8 \mathrm{mM}$. The $\mathrm{Cr}$ ion concentrations were approximately half those of $\mathrm{Zn}$, to compensate for the higher toxicity of $\mathrm{Cr}$ (III) for plants (Hara and Sonoda 1979). Five replicates (plants) of each treatment were randomly distributed and grown under glasshouse conditions for 5 weeks in June and July. The average temperature was $36-18^{\circ} \mathrm{C}$ (day/night), the relative humidity $31-59 \%$, the maximum global solar irradiance $1,353 \mathrm{~W}$ $\mathrm{m}^{-2}$, and the transmission of the greenhouse covers $51 \%$. Nutritive solution was renewed regularly.

In vivo measurements

Before collecting the plants, in vivo measurements were taken. Chlorophyll content on leaf area basis was measured at the base, centre and tip of four representative mature pre-bloom leaves per plant using a portable chlorophyll meter (SPAD-502 Minolta, Illinois, USA), following Krugh et al. (1994). A reading checker of $72.4 \pm 0.3$ was used to calibrate the apparatus. Chlorophyll fluorescence was measured with a modulated fluorometer (Hansatech 
Fluorescence Monitoring System FMS2, Norfolk, UK) to obtain estimates of maximum quantum yield $\left(F_{v} / F_{m}\right)$ after $30 \mathrm{~min}$ of dark adaptation and of relative quantum yield $\left(\Phi_{\text {PSII }}\right)$ measured at environmental light (Genty et al. 1989). Plants were then thoroughly washed in tap water, gently wrapped in absorbent paper to remove excess water and weighed to record the increase in biomass. Each plant was divided into leaves, rhizomes and roots, and each section was weighed separately. The underground organs were not desorbed to preserve the fraction of metal adsorbed to cell walls, which would also be collected after harvest in phytoremediation systems. A portion of each fresh sample was ground in liquid nitrogen and stored at $-80^{\circ} \mathrm{C}$ until analysis. The remaining fresh sample was oven-dried at $60^{\circ} \mathrm{C}$ until constant weight, ground in an agate mortar and passed through a $0.05-\mathrm{mm}$ sieve.

Photosynthetic pigment content

The chlorophyll and carotenoid concentration of leaves was measured on extracts of frozen leaf samples in $80 \%$ acetone. Pigment contents were calculated from absorbance at wavelengths $663.2,646.8$, and $470.0 \mathrm{~nm}$, as described by Lichtenthaler (1987). The absorbance values were measured in the extracts by means of a UV-160 spectrophotometer.

\section{Element composition}

Two replicates of each frozen sample were digested overnight at $90^{\circ} \mathrm{C}$ in $\mathrm{HNO}_{3}-\mathrm{H}_{2} \mathrm{O}_{2}$ mixture $1: 1 \mathrm{v} / \mathrm{v}$. The $\mathrm{Al}$, $\mathrm{Ca}, \mathrm{Cu}, \mathrm{Fe}, \mathrm{K}, \mathrm{Mg}, \mathrm{Mn}, \mathrm{S}$ and $\mathrm{P}$ content of the extracts was determined by inductively coupled plasma optical emission spectrometry (ICP-OES) and by inductively coupled plasma mass spectrometry (ICP-MS) using a Perkin Elmer Optima-3200RL and a Perkin Elmer Elan-6000 apparatus, respectively. A blank and a sample of aquatic plant (Trapa natans L, CRM 596) or sea lettuce (Ulva lactuca L, CRM 279) certified reference material from the Community Bureau of Reference $\left(\mathrm{BCR}^{\circledR}\right)$, were processed in the same way and analysed per 12 samples. Element content determination was performed in the technical services of the University of Barcelona (Serveis Científicotècnics). Ash content was determined by furnacing samples at $500^{\circ} \mathrm{C}$ for $6 \mathrm{~h}$ or until constant weight.

Stable isotope composition

For each plant, a sample of dried leaf, rhizome, and root tissue was ground into a fine powder, and $1 \mathrm{mg}$ was weighed in tin cups. The total $\mathrm{C}$ and $\mathrm{N}$ content of samples was analysed using an Elemental Analyser (EA, Carlo Erba 2100, Milan, Italy), which was interfaced with an Isotope Ratio Mass Spectrometer (IRMS, Thermo-Finnigan Deltaplus Advantage, Bremen, Germany) to analyse ${ }^{13} \mathrm{C} /{ }^{12} \mathrm{C}$ and ${ }^{15} \mathrm{~N} /{ }^{14} \mathrm{~N}$ ratios. Results were expressed as $\delta^{13} \mathrm{C}$ and $\delta^{15} \mathrm{~N}$ values, using a secondary standard calibrated against Vienna Pee Dee Belemnite calcium carbonate (VPDB) for C, and air for N. Analytical precision was of $0.1 \%$. All analyses were undertaken at the Colorado Plateau Stable Isotope Laboratory (CPSIL, Northern Arizona University). $\delta^{13} \mathrm{C}$ and $\delta^{15} \mathrm{~N}$ were calculated as:

$\delta^{13} \mathrm{C}=\left(\left(\frac{{ }^{13} \mathrm{C} /{ }^{12} \mathrm{C}_{\text {sample }}}{{ }^{13} \mathrm{C} /{ }^{12} \mathrm{C}_{\text {standard }}}\right)-1\right) \times 1,000$
$\delta^{15} \mathrm{~N}=\left(\left(\frac{{ }^{15} \mathrm{~N} /{ }^{14} \mathrm{~N}_{\text {sample }}}{{ }^{15} \mathrm{~N} /{ }^{14} \mathrm{~N}_{\text {standard }}}\right)-1\right) \times 1,000$.

Statistical methods

ANOVA (analysis of variance) was performed on the basis of a one-factor design using SPSS (Statistical Package for the Social Sciences) version 14.0 for Windows. Logarithmic transformation was used when data did not meet the assumption of equal variances. Student-Newman-Keuls post hoc tests were performed to assess the differences between groups. Sigma Plot version 10.0 was used for graphic edition. Cluster analysis was done using Gene Cluster (Standford University, USA) on standardized averages, and distances between clusters were established by average linkage clustering.

\section{Results}

Biomass, water content and chlorophyll

Plant growth was strongly impaired by heavy metal stress. Both $\mathrm{Cr}$ and $\mathrm{Zn}$ decreased fresh weight increment $(\Delta \mathrm{FW})$ and dry weight increment $(\Delta \mathrm{DW})$ of the whole plant after 5 weeks of treatment (Table 1). The treatment with $\mathrm{ZnCl}_{2}$ did not disturb plant growth at low concentrations, but at $100 \mu \mathrm{g} \mathrm{ml}^{-1} \Delta \mathrm{FW}$ and $\Delta \mathrm{DW}$ fell dramatically (59 and $65 \%$, respectively). The effect of $\mathrm{CrCl}_{3}$ was gradual, to reach a decrease of $61 \%(\Delta \mathrm{FW})$ and $44 \%(\Delta \mathrm{DW})$ at $200 \mu \mathrm{g} \mathrm{ml} \mathrm{m}^{-1}$.

To determine whether growth was equally inhibited in all plant organs, final fresh weight (FW) and final dry weight (DW) of leaves, rhizomes and roots were recorded separately (Table 1). Increasing $\mathrm{Zn}$ and $\mathrm{Cr}$ reduced the $\mathrm{FW}$ of leaves (Table 1) up to $48 \%\left(200 \mu \mathrm{g} \mathrm{ml}^{-1} \mathrm{ZnCl}_{2}\right)$ and $56 \%\left(100 \mu \mathrm{g} \mathrm{ml}^{-1} \mathrm{CrCl}_{3}\right)$. The $\mathrm{FW}$ and the $\mathrm{DW}$ of all organs showed strong decrease when supplied with high concentrations of metals, but these variations were only significant in leaves due to the high variability of the 


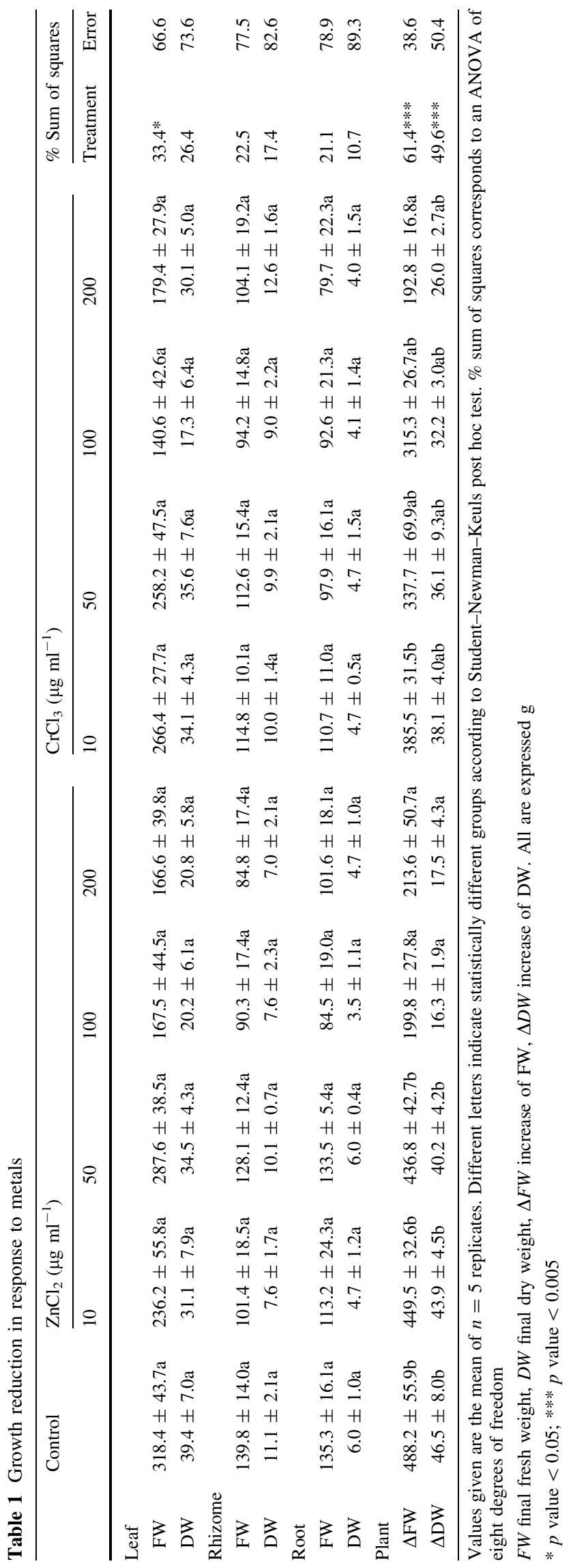

response. Nevertheless, it is of note that high $\mathrm{Zn}$ (100 or $200 \mu \mathrm{g} \mathrm{ml}^{-1} \mathrm{ZnCl}_{2}$ ) reduced DW up to $48 \%$ (leaves), $37 \%$ (rhizomes) and $22 \%$ (roots). In contrast, DW was $33 \%$ lower in roots and $24 \%$ lower in leaves, but $14 \%$ greater in rhizomes treated with high concentrations of $\mathrm{Cr}$, than in controls. Water content (WC) calculated as a percentage was $5 \%$ lower in leaves and rhizomes treated with $200 \mu \mathrm{g} \mathrm{ml}^{-1} \mathrm{CrCl}_{3}$, and remained stable in all the other treatments (results not shown).

The biomass allocation was altered (Fig. 1) as a result of the marked reduction of leaf DW, which accounts for most of the total biomass of I. pseudacorus. The root:shoot dry matter partitioning $(R / S)$ was affected from $100 \mu \mathrm{g} \mathrm{ml} \mathrm{m}^{-1}$ $\mathrm{CrCl}_{3}$ upwards (Fig. 1b). ANOVA performed on the same data confirmed the effect of $\mathrm{Cr}$ treatment on $R / S$ ( $p$ value $=0.03$ ). The $R / S$ was proportional to the external Zn concentration (Fig. 1a), but the tendency was not significant ( $p$ value $=0.18$ )

No significant effect of metal concentration in growth media was found on either $F_{v} / F_{m}, \Phi_{\text {PSII }}$ or photosynthetic pigment content. The means of plants treated with the highest metal concentrations scarcely differed from those of control plants (Table 2).

\section{Metal concentration and extraction}

Metal concentration in leaf, rhizome and root tissues increased with increasing concentration in the growth media, both for $\mathrm{Cr}$ and $\mathrm{Zn}$ treatments (Fig. 2). The roots achieved the highest concentrations $\left(4.8 \mathrm{mg} \mathrm{g}^{-1} \mathrm{Zn}\right.$ and $10.1 \mathrm{mg} \mathrm{g}^{-1} \mathrm{Cr}$ ), followed by rhizomes $\left(2.1 \mathrm{mg} \mathrm{g}^{-1} \mathrm{Zn}\right.$ and $0.7 \mathrm{mg} \mathrm{g}^{-1} \mathrm{Cr}$ ). Leaves showed a remarkable capacity to retain $\mathrm{Zn}$, reaching $0.6 \mathrm{mg} \mathrm{g}^{-1}$. Chromium concentration was lower than $\mathrm{Zn}$ concentration in leaves and rhizomes, but higher in roots.

Despite the reduction of plant growth at high metal concentrations (Table 1), the amount of $\mathrm{Cr}$ and $\mathrm{Zn}$ extracted (calculated as the amount of metal extracted per unit of biomass) continued to increase as a result of the rising concentration in tissues. Chromium extraction (Table 3) was greater in roots than in rhizomes and leaves. The portion extracted by leaves was very small. The average total extraction per individual plant at the maximum $\mathrm{Cr}$ supply was $70.6 \mathrm{mg}$. Similarly, Zn extraction was greater in roots than in rhizomes and leaves, which extracted a similar amount. The average total extraction per individual plant at the highest $\mathrm{Zn}$ supply was $56.8 \mathrm{mg}$, thus $24 \%$ lower than in the highest $\mathrm{Cr}$ treatment. This in spite of the $\mathrm{Zn}$ ion concentration supplied being twice as much as that of $\mathrm{Cr}(1.5 \mathrm{mM} \mathrm{Zn}$ vs. $0.08 \mathrm{mM} \mathrm{Cr}$ for $200 \mu \mathrm{g} \mathrm{ml}^{-1}$ treatments). However, the amount of $\mathrm{Zn}$ extracted by leaves was 10 -fold that of $\mathrm{Cr}$ (1.4 mg Cr vs. $14.2 \mathrm{mg} \mathrm{Zn).}$ 


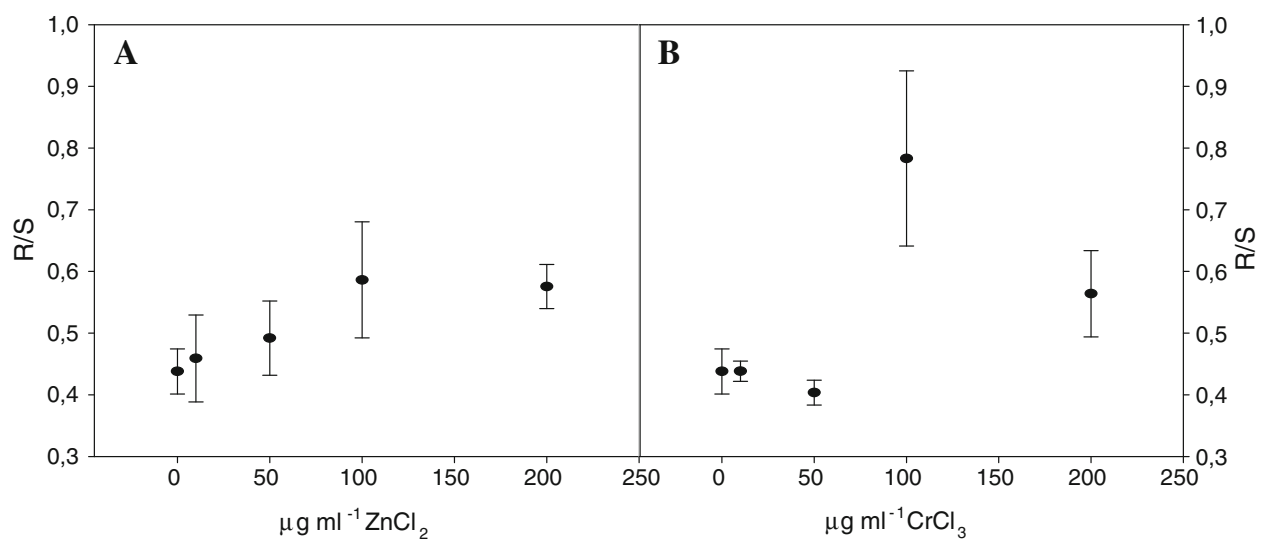

Fig. 1 Effect of treatments on biomass distribution ratio. Plants were grown in nutritive solution containing $\mathrm{ZnCl}_{2}$ or $\mathrm{CrCl}_{3} \cdot 6 \mathrm{H}_{2} \mathrm{O}$ at 0,10 , 50,100 , and $200 \mu \mathrm{g} \mathrm{ml}^{-1}$. Root to shoot ratio $(R / S)$ was calculated from final DW data, where "Shoot" designates the biomass of the

Table 2 Chlorophyll fluorescence and content of photosynthetic pigments of controls and plants treated with the highest metal concentrations $\left(200 \mu \mathrm{g} \mathrm{ml}^{-1}\right.$ of the chloride salts)

\begin{tabular}{lrrr}
\hline & \multicolumn{1}{l}{ Control } & \multicolumn{1}{l}{ Zn } & \multicolumn{1}{l}{ Cr } \\
\hline$\Phi_{\text {PSII }}$ & $0.75 \pm 0.01$ & $0.74 \pm 0.02$ & $0.76 \pm 0.01$ \\
$F_{v} / F_{m}$ & $0.84 \pm 0.00$ & $0.84 \pm 0.01$ & $0.84 \pm 0.01$ \\
$\mathrm{Chl}_{\mathrm{a}}$ & $0.83 \pm 0.05$ & $0.68 \pm 0.14$ & $0.85 \pm 0.06$ \\
$\mathrm{Chl}_{\mathrm{b}}$ & $0.32 \pm 0.02$ & $0.28 \pm 0.05$ & $0.34 \pm 0.03$ \\
$\mathrm{Chl}_{(\mathrm{a}+\mathrm{b})}$ & $1.16 \pm 0.07$ & $0.95 \pm 0.19$ & $1.19 \pm 0.08$ \\
$\mathrm{Car}$ & $0.19 \pm 0.01$ & $0.16 \pm 0.03$ & $0.21 \pm 0.02$ \\
$\mathrm{Chl}_{\mathrm{a}} / \mathrm{Chl}$ & $2.60 \pm 0.04$ & $2.42 \pm 0.05$ & $2.51 \pm 0.04$ \\
$\mathrm{Chl}_{(\mathrm{a}+\mathrm{b})} / \mathrm{Car}$ & $6.08 \pm 0.11$ & $5.63 \pm 0.21$ & $5.88 \pm 0.18$ \\
$\mathrm{SPAD}$ & $60.04 \pm 2.90$ & $56.10 \pm 5.5$ & $54.04 \pm 3.36$ \\
\hline
\end{tabular}

Values are the average of $n=5$ replicates \pm standard error. Quantum yield of PSII photochemistry $\left(\Phi_{\text {PSII }}\right)$, maximum quantum yield $\left(F_{v} / F_{m}\right)$ and SPAD values are dimensionless. Pigment content is displayed in $\mathrm{mg} \mathrm{g}^{-1}$. None of the treatments induced significant differences according to ANOVA ( $p$ values not shown)

\section{$\mathrm{C}$ and $\mathrm{N}$ content and isotopic composition}

In response to the addition of either of the two metals, but particularly $\mathrm{Cr}$, leaves, rhizomes and roots became isotopically heavier (Table 4). However, the increment of $\delta^{13} \mathrm{C}$ did not attain significance in rhizomes due to the high variability between samples. Increasing $\mathrm{Cr}$ also augmented the $\mathrm{C} / \mathrm{N}$ ratio, more markedly in roots $(32.4 \%)$ than in rhizomes $(21.7 \%)$. In agreement, $\% \mathrm{~N}$ decreased $32.1 \%$ in roots and $19.4 \%$ in rhizomes of $\mathrm{Cr}$-exposed plants. The $\% \mathrm{C}$ and $\delta^{15} \mathrm{~N}$ remained stable (results not shown).

\section{Element content}

The trees generated from element content cluster analysis (Fig. 3) clearly separated controls from treatments, and $\mathrm{Zn}$ emerged tissues, and "Root" the biomass of submerged tissues, with rhizomes and roots summed together. Values are the average of $n=5$ replicates; error bars indicate the standard errors. The respective ANOVA $p$ values were of 0.18 for $\mathbf{a}$, and of 0.03 for $\mathbf{b}$

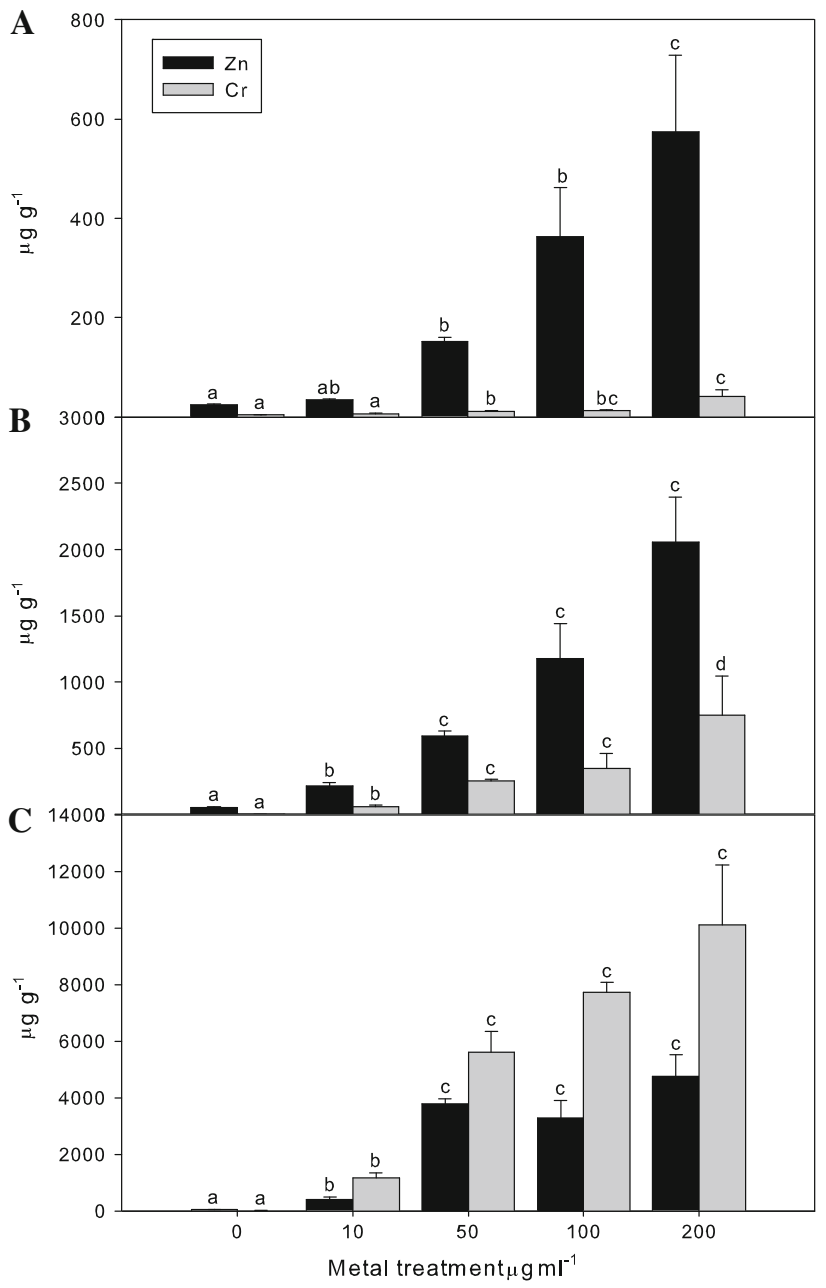

Fig. 2 Concentration of metals in I. pseudacorus leaves (a), rhizomes (b) and roots (c). Values are the average of $n=5$ replicates. Different letters indicate significant differences between groups according to Student-Newman-Keuls post hoc test. Data transformation $\log (y+1)$ was conducted to meet the equal variances assumption 
Table 3 Accumulation of heavy metals in tissues, calculated as the metal concentration multiplied by the biomass of each plant section

\begin{tabular}{|c|c|c|c|c|c|c|c|}
\hline & \multirow[t]{2}{*}{ Control } & \multicolumn{4}{|c|}{ Metal treatment $\left(\mu \mathrm{g} \mathrm{ml}^{-1}\right)$} & \multicolumn{2}{|c|}{$\%$ Sum of squares } \\
\hline & & 10 & 50 & 100 & 200 & Treatment & Error \\
\hline \multicolumn{8}{|l|}{$\mathrm{ZnCl}_{2}$} \\
\hline Leaf & $1.0 \pm 0.2 \mathrm{a}$ & $1.4 \pm 0.1 \mathrm{a}$ & $5.2 \pm 0.7 b$ & $8.5 \pm 0.5 c$ & $14.2 \pm 1.1 \mathrm{~d}$ & $93.6 * * *$ & 6.4 \\
\hline Rhizome & $0.6 \pm 0.1 \mathrm{a}$ & $2.2 \pm 0.2 \mathrm{ab}$ & $6.0 \pm 0.6 b c$ & $9.1 \pm 1.5 \mathrm{c}$ & $17.0 \pm 2.7 \mathrm{~d}$ & $81.1 * * *$ & 18.9 \\
\hline Root & $0.3 \pm 0.1 \mathrm{a}$ & $2.7 \pm 0.6 \mathrm{a}$ & $22.7 \pm 2.2 b$ & $16.8 \pm 5.2 b$ & $25.6 \pm 3.3 b$ & $75.8 * * *$ & 24.2 \\
\hline \multicolumn{8}{|l|}{$\mathrm{CrCl}_{3}$} \\
\hline Leaf & $0.1 \pm 0.0 \mathrm{a}$ & $0.2 \pm 0.1 \mathrm{a}$ & $0.3 \pm 0.0 \mathrm{a}$ & $0.4 \pm 0.0 \mathrm{a}$ & $1.4 \pm 0.6 \mathrm{~b}$ & $45.1 * *$ & 54.9 \\
\hline Rhizome & $0.1 \pm 0.0 \mathrm{a}$ & $0.6 \pm 0.1 \mathrm{a}$ & $2.0 \pm 0.1 \mathrm{a}$ & $4.7 \pm 1.6 \mathrm{ab}$ & $9.3 \pm 4.1 b$ & $42.8 * *$ & 57.2 \\
\hline Root & $0.0 \pm 0.0 \mathrm{a}$ & $5.6 \pm 1.1 \mathrm{a}$ & $17.9 \pm 3.1 \mathrm{ab}$ & $38.6 \pm 8.7 \mathrm{ab}$ & $59.9 \pm 24.8 b$ & $46.7 * *$ & 53.3 \\
\hline
\end{tabular}

Values are means of $n=5$ replicates, expressed in mg. Different letters indicate significant differences between groups according to StudentNewman-Keuls test. \% of the sum of squares corresponds to an ANOVA of four degrees of freedom

** $p$ value $<0.01 ; * * * p$ value $<0.005$

from $\mathrm{Cr}$ treatments. Except for leaves, treatments with high concentrations of metals (100 and $200 \mu \mathrm{g} \mathrm{ml}^{-1}$ ) were closer to each other than to those applying low concentrations (10 and $50 \mu \mathrm{g} \mathrm{ml}^{-1}$ ), which grouped together.

Both $\mathrm{Cr}$ and $\mathrm{Zn}$ stress induced diverse changes in the elemental composition and ash content $\left(m_{\mathrm{a}}\right)$ of plants (Tables 5, 6, 7). Chromium and Zn stress had a similar effect on some elements. Both caused an increment in Mn (leaves), and $\mathrm{P}$ content (roots), together with reduced $\mathrm{Al}$ (rhizomes) and $\mathrm{Cu}$ (rhizomes and leaves) content and $\mathrm{Al}, \mathrm{S}$, $\mathrm{Mn}, \mathrm{Mg}$ and $\mathrm{Ca}$ content (roots). The other effects detected were of an opposite sign under $\mathrm{Cr}$ and $\mathrm{Zn}$ stress. In leaves, $\mathrm{Cr}$ decreased $\mathrm{Fe}, \mathrm{S}$, and Ca content, whereas $\mathrm{Zn}$ increased $\mathrm{P}$ and $\mathrm{Ca}$. The quantification of $\mathrm{Mg}, \mathrm{Fe}, \mathrm{S}$, and $\mathrm{Al}$ in leaves in the $100 \mu \mathrm{g} \mathrm{ml}^{-1} \mathrm{ZnCl}_{2}$ treatment was inconsistent with the other $\mathrm{Zn}$ treatments, and must thus be interpreted with caution. In rhizomes, high $\mathrm{Cr}$ diminished the concentration of $\mathrm{Ca}, \mathrm{Fe}, \mathrm{Mg}$ and $\mathrm{K}$, whereas $\mathrm{Zn}$ had the opposite effect on $\mathrm{Ca}$ and $\mathrm{K}$. In roots, high $\mathrm{Zn}$ decreased $\mathrm{Fe}$, whereas all the $\mathrm{Zn}$ treatments increased $\mathrm{Cu}$ and $\mathrm{K}$. High $\mathrm{Cr}$ decreased $\mathrm{Cu}$ and $\mathrm{K}$.

The response of $m_{\mathrm{a}}$ to $\mathrm{Zn}$ varied. This parameter increased in leaves (Table 5) while in rhizomes and roots (Tables 6, 7) it decreased; however, none of these deviations were higher than $12 \%$. In contrast, $\mathrm{Cr}$ decreased the $m_{\mathrm{a}}$ of leaves $(5.4 \%)$, rhizomes $(38.2 \%)$ and roots $(23.7 \%)$.

\section{Discussion}

Iris pseudacorus was highly tolerant to $\mathrm{Zn}$ and $\mathrm{Cr}$ stress, as all plants survived the high metal concentrations supplied. Both metals were accumulated preferentially in roots, especially $\mathrm{Cr}$, but $\mathrm{Zn}$ was also exported to leaves, in agreement with the literature (Deng et al. 2006; Mazej and Germ 2009; Qian et al. 1999). According to the definition by Baker and Brooks (1989), a plant must concentrate $\mathrm{Cr}$ to a minimum $1,000 \mu \mathrm{g} \mathrm{g}^{-1}$, and $\mathrm{Zn}$ to a minimum $10,000 \mu \mathrm{g} \mathrm{g}^{-1}$ in its leaves to be considered a hyperaccumulator. These levels are much higher than that observed in the present experiment. Samecka-Cymerman and Kempers (2001) analysed leaves of I. pseudacorus naturally growing in a Polish anthropogenic lake with $120 \mu \mathrm{g} \mathrm{g}^{-1} \mathrm{Cr}$ and $11 \mu \mathrm{g} \mathrm{g}^{-1} \mathrm{Zn}$ in the sediment. These levels are comparable to our treatments with $10-50 \mu \mathrm{g} \mathrm{ml}^{-1} \mathrm{ZnCl}_{2}$ (which contain 4.8-24.0 $\mu \mathrm{g} \mathrm{ml}^{-1} \mathrm{Zn}$, respectively), but are approximately threefold our highest $\mathrm{Cr}$ treatment (39.0 $\mu \mathrm{g} \mathrm{ml}^{-1} \mathrm{Cr}$ ). The concentration of $\mathrm{Zn}$ in leaves in those conditions reached $21 \mu \mathrm{g} \mathrm{g}^{-1}$, which is comparable to our $35 \mu \mathrm{g} \mathrm{g}^{-1}$ at $10 \mu \mathrm{g} \mathrm{ml}^{-1} \mathrm{ZnCl}_{2}$. However, the concentration of $\mathrm{Cr}$ was clearly inferior, only $4 \mu \mathrm{g} \mathrm{g}^{-1}$ versus our $41 \mathrm{\mu g} \mathrm{g}^{-1}$. This discrepancy is possibly the result of the limited solubility of $\mathrm{Cr}$ in lake sediments, as described by Polyák and Hlavay (1999).

Our results demonstrated a specific response of the biomass acquisition and water content of plant sections to $\mathrm{Zn}$ and $\mathrm{Cr}$, owing to their being essential and nonessential nutrient, respectively. The pattern shown by $\mathrm{Zn}$-treated plants is consistent with the typical growth response to essential nutrients, which enhance growth at a sub-optimal or optimal concentration, but become toxic above a critical level (Marschner 1995). This threshold would lie between 50 and $100 \mu \mathrm{g} \mathrm{ml}^{-1} \mathrm{ZnCl}_{2}$ for I. pseudacorus. In contrast, $\mathrm{Cr}$ is a nonessential element that promotes growth only at very low doses (Bonet et al. 1991). At the Cr concentrations used in our study, growth was not enhanced but gradually inhibited as the external $\mathrm{Cr}$ concentration increased. 


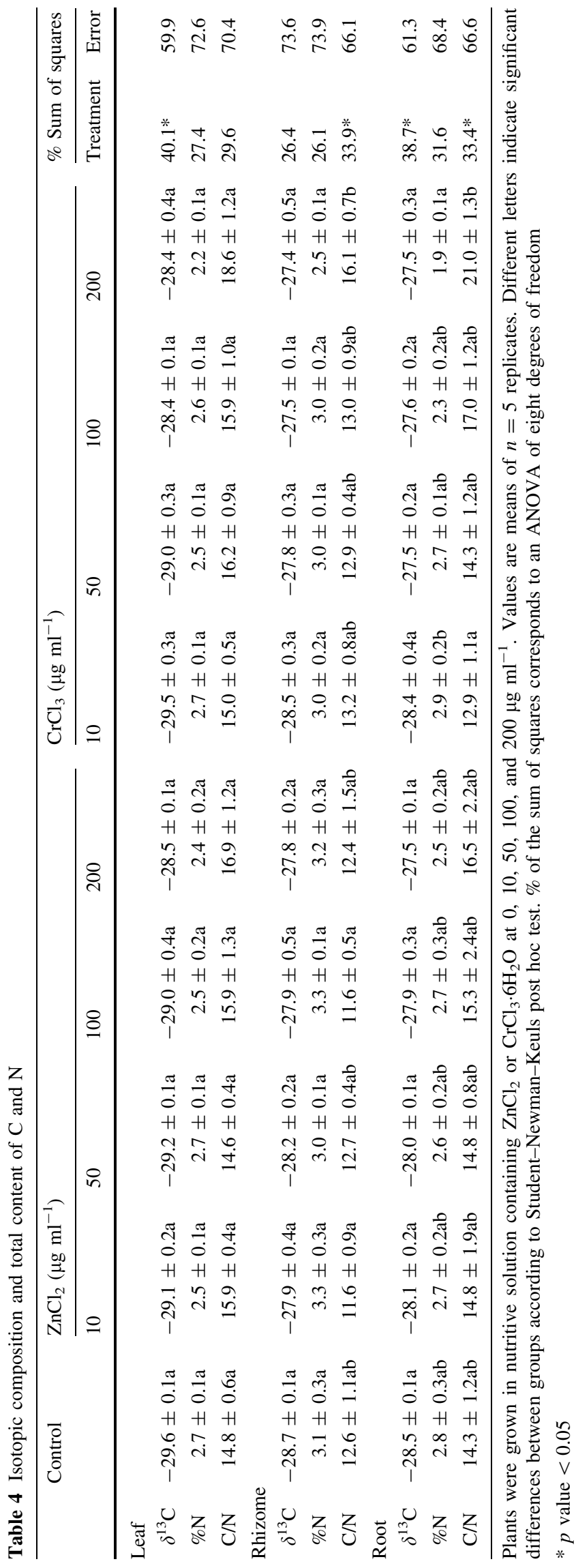

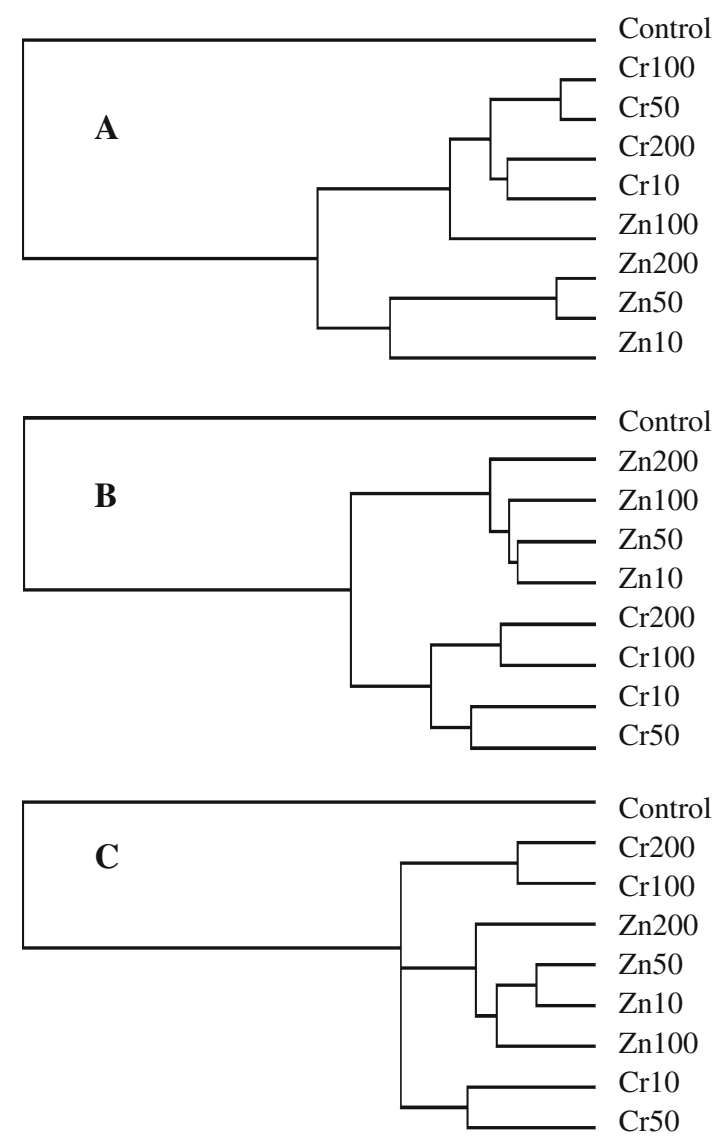

Fig. 3 Cluster analysis for the mineral content of leaves (a), bulbs (b) and roots (c). Elements analysed were $\mathrm{Al}, \mathrm{Ca}, \mathrm{Cu}, \mathrm{Fe}, \mathrm{K}, \mathrm{Mg}, \mathrm{Mn}$, $\mathrm{S}$ and $\mathrm{P}$. Plants were grown in nutritive solution containing $\mathrm{ZnCl}_{2}$ or $\mathrm{CrCl}_{3} \cdot 6 \mathrm{H}_{2} \mathrm{O}$ at $0,10,50,100$, and $200 \mu \mathrm{g} \mathrm{ml}^{-1}$. Values were the average of $n=5$ replicates

The greater growth reduction observed in $\mathrm{Zn}$-treated leaves is coherent with the higher amount of $\mathrm{Zn}$ transported to leaves. Zinc molar concentration is also twice as high as that of $\mathrm{Cr}$ in equivalent treatments $(1.5$ vs. $0.8 \mathrm{mM}$ at $200 \mu \mathrm{g} \mathrm{ml}^{-1}$ ). The reduction of growth caused by $\mathrm{Cr}$ was due both to poor dry matter acquisition, which affected the roots more severely, and to reduced plant water content. Both effects are derivable from root damage and consistent with the preeminent role of roots in $\mathrm{Cr}$ retention and the restricted exportation of this metal to leaves. The decrease in $m_{\mathrm{a}}$ in Cr-stressed roots was lower than expected; most probably because the high amounts of $\mathrm{Cr}$ accumulated there (Table 3) partially compensated the decrease of other elements. A similar process might have occurred in Zn-stressed plants.

There is ample evidence of the deleterious effects of $\mathrm{Cr}$ and $\mathrm{Zn}$ at various stages of photosynthesis and biosynthesis of chlorophyll (Ali et al. 2006; Chandra and Kulshreshtha 2004; Küpper et al. 1996; Oláh et al. 2010; Prasad and Strzałka 2002; Todeschini et al. 2011). Nevertheless, our 


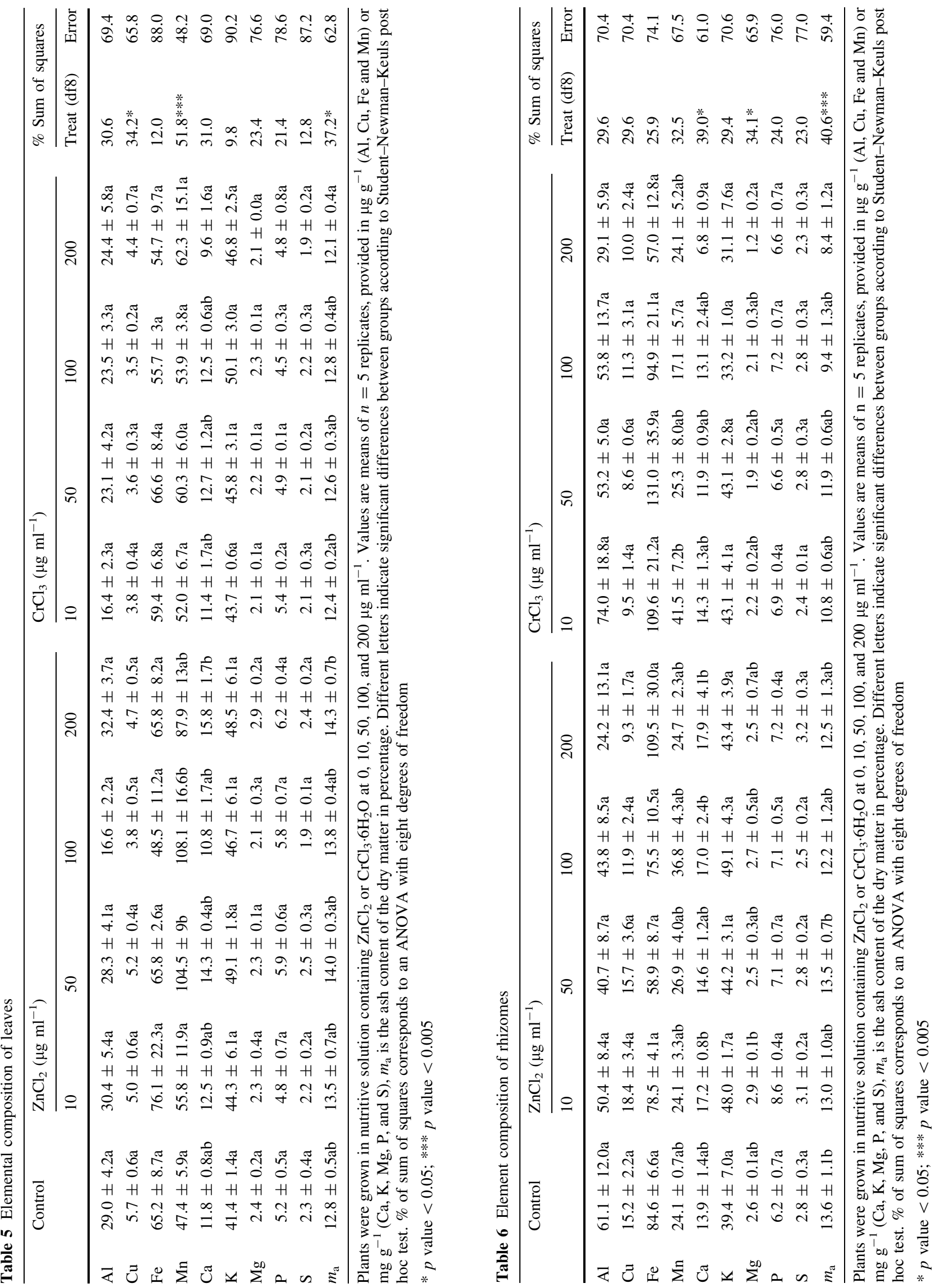




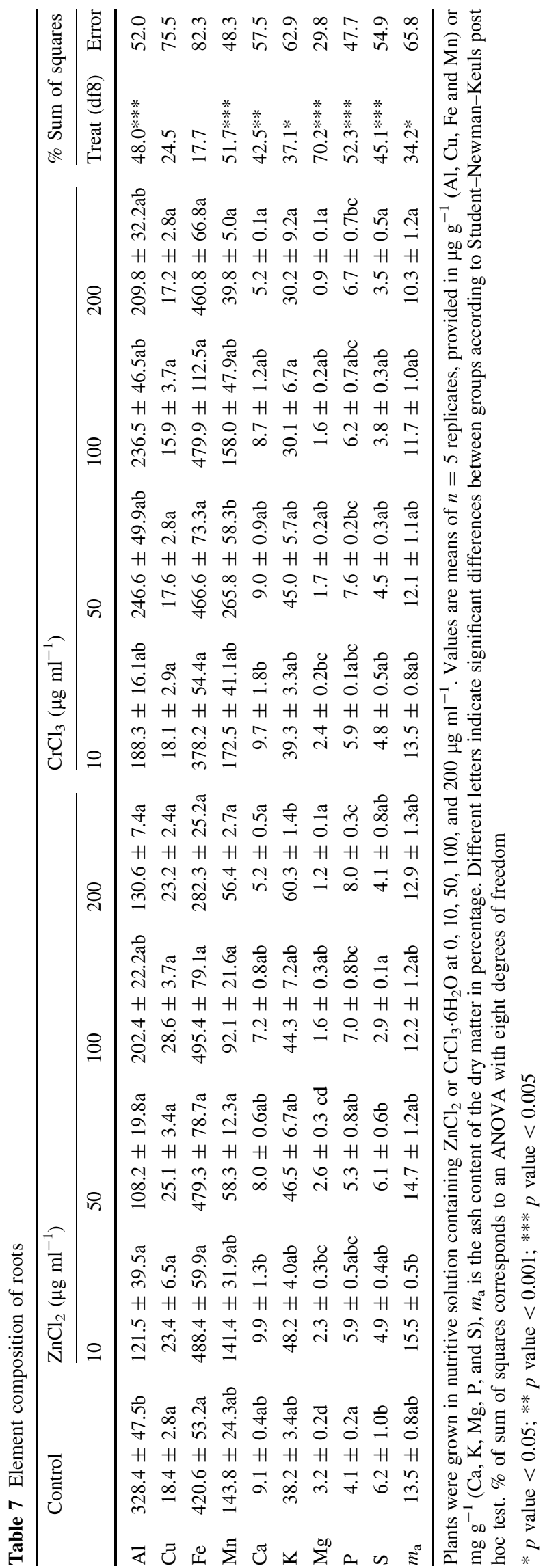

results showed no harmful effect of $\mathrm{Cr}$ or $\mathrm{Zn}$ either on photosynthetic pigment content or on chlorophyll fluorescence. This observation implies that the efficiency of the light phase of photosynthesis was preserved. Despite the high concentration of metals supplied, PSII appeared fully functional: $\Phi_{\text {PSII }}$ values were high, in agreement with the low intensity of environmental light, and $F_{v} / F_{m}$ values were optimal. $F_{v} / F_{m}$ is widely accepted as a rigorous measure of photo-inhibition, whereas $\Phi_{\text {PSII }}$ is a measure of photochemistry, which is related to electron transport (effective quantum yield) and thus to photosynthesis (Maxwell and Johnson 2000). The correlation of $\Phi_{\text {PSII }}$ with $\mathrm{CO}_{2}$ fixation in $\mathrm{C}_{3}$ plants is not always linear, but can be modified depending on the electron fractionation between photosynthesis and photorespiration (Krall and Edwards 1992). Dhir et al. (2008) studied the photosynthetic performance of Salvinia natans $\mathrm{L}$. in response to $\mathrm{Cr}$ and $\mathrm{Zn}$ stress, and reported that pigment content and RuBisCo activity was decreased by both metals, while $F_{v} / F_{m}$ was decreased only by $\mathrm{Zn}$. A reduction in $\mathrm{CO}_{2}$ fixation as a result of heavy metal stress is therefore not necessarily reflected in chlorophyll fluorescence, and a decay of assimilation cannot be excluded from our results, even if pigment content was not affected.

The correlation of $\delta^{13} \mathrm{C}$ with intercellular $\mathrm{CO}_{2}$ concentration $\left(C_{\mathrm{i}}\right)$ has been extensively demonstrated (Farquhar 1983). The mild increase of $\delta^{13} \mathrm{C}$ in response to the high metal concentrations supplied indicates that the stomatal aperture was restricted to some extent, which could affect intrinsic $\mathrm{CO}_{2}$ fixation. However, the changes in $\delta^{13} \mathrm{C}$ were too subtle, in our opinion, to be the only cause of the notable reduction in growth detected. Wei et al. (2008) observed that $\delta^{13} \mathrm{C}$ was slightly affected by $\mathrm{Cd}$ exposure in mangrove (Aegiceras corniculatum (L.) Blanco) and roots were more sensitive than leaves. These authors observed that $\delta^{13} \mathrm{C}$ also differed between plant parts, with assimilating organs showing lower values than non-assimilating or storage organs. In our study, leaves were isotopically lighter than rhizomes and roots, but $\delta^{13} \mathrm{C}$ was equally responsive in all tissues. The $\delta^{13} \mathrm{C}$ values were between -30.58 and $-25.88 \%$, which is within the range of $\mathrm{C}_{3}$ plants (Boutton et al. 1998). Average values across all plant parts and growing conditions ranged from 29.5 to $-27.4 \%$, which again is usual for $\mathrm{C}_{3}$ plants. The $\mathrm{WC}$ and $m_{\mathrm{a}}$ reduction noted in response to $\mathrm{Cr}$ is therefore best attributed to other causes than the subtle inhibition of transpiration, such as restrained water and nutrient uptake induced by severe root damage. Water uptake is directly connected to the deposition and absorption of minerals (Bakker and Elbersen 2005).

Zinc and $\mathrm{Cr}$ disturbed not only plant growth, but also biomass allocation. The most plausible explanation for this is a source-to-sink carbohydrate relocation from leaves to 
non-assimilating tissues. The growth decrease per plant section was ranked leaf $>$ rhizome $>$ root, which caused the constant increase of $R / S$ with increasing $\mathrm{Zn}$ concentration. This finding is consistent with the $\mathrm{Zn}$ accumulation pattern and suggests that roots were the most relevant sink tissue. In contrast, although roots accumulated higher amounts of $\mathrm{Cr}$ and showed a stronger growth inhibition, $R / S$ increased abruptly at high $\mathrm{Cr}$ treatments as a result of the weight increase of the rhizomes. This observation points to rhizomes as the most demanding sink tissue in $\mathrm{Cr}$-stressed plants. The roots treated with $\mathrm{Cr}$ accumulated a significantly higher amount of metal and showed more symptoms of damage, which may explain a restricted unload of carbohydrates.

The carbohydrate requirements of the roots and rhizomes of a plant under heavy metal stress might increase as a result of active detoxification mechanisms, such as ROS scavenging, compartmentalization, damage repair, cell wall thickening, or the synthesis of secondary metabolites. Some authors report increased dark respiration and ATP in response to heavy metal exposure, which may exert a protective role (Pavlovič et al. 2006; Romanowska et al. 2002). This notion is also in agreement with the reduced growth and increased P concentration, especially in roots, where the demand for ATP in order to neutralize the negative effects of excess $\mathrm{Zn}$ or $\mathrm{Cr}$ should be most augmented. $\mathrm{P}$ is assimilated as ATP, the chemical energy storage of the cell. The decrease in $\mathrm{P}$ content in Cr-treated leaves could be interpreted as relocation to P-demanding roots. Stobrawa and Lorenc-Plucińska (2007) found no evidence of increased respiration in the fine roots of Populus nigra L. growing in a site polluted by multiple metals; however, sucrose breakdown was activated and the level of soluble carbohydrates lowered. Those authors proposed that sucrose is used for the synthesis of cell wall polysaccharides (callose or cellulose) or secondary metabolites.

A high $R / S$ has also been described in response to nutrient or water deficiency (Hermans et al. 2006; Price et al. 2002), as a tolerance mechanism that reduces transpiration and redirects carbohydrates to increase the surface available for water and nutrient uptake. Chromium (III) and $\mathrm{Zn}$ are passively taken up and retained by cation exchange sites in cell walls (Marschner 1995; Skeffington et al. 1976). An excessive concentration of these metals can compete with other polyvalent cations such as $\mathrm{Mg}, \mathrm{Mn}$, and $\mathrm{Ca}$ for the formation of coordination complexes, and induce mineral nutrient deficiency. This would explain the decreased levels of $\mathrm{Al}, \mathrm{Mg}, \mathrm{Mn}$, and $\mathrm{Ca}$ in $\mathrm{Zn}$-treated roots and of $\mathrm{Al}, \mathrm{Mg}, \mathrm{Mn}, \mathrm{Ca}$, and $\mathrm{K}$ in $\mathrm{Cr}$-treated roots in our study, and is in agreement with the response of $m_{\mathrm{a}}$. Increased $\mathrm{P}$ concentration and decreased $\mathrm{S}$ concentration have been described in cauliflower plants under $\mathrm{Cr}$ stress (Chatterjee and Chatterjee 2000). Sulphur is absorbed by plant roots as sulphate by means of a proton symporter (like nitrate and phosphate), and stored in vacuoles (Buchner et al. 2004). Sulphur may be displaced from metal-occupied vacuoles of roots and rhizomes, where $\mathrm{Cr}$, $\mathrm{Zn}$ and other heavy metals are compartmentalized to prevent their toxic effects on cell metabolism. This notion is coherent with previous data from TEM microanalysis of the vacuoles of Cr-exposed I. pseudacorus rhizomes (Caldelas et al. 2012), which showed high of $\mathrm{S}$ and $\mathrm{Cr}$ contents. In summary, a greater number of elements showed a tendency to reduce their contents in $\mathrm{Cr}$-stressed plants than in $\mathrm{Zn}$-stressed plants, and roots were more affected by this decrease than leaves and rhizomes. However, when considering the previous results, that WC was lower in $\mathrm{Cr}$-stressed rhizomes and roots must be taken into account. This lower WC might have caused the concentration of some elements to be higher in these tissues, and does not imply that uptake has increased or relocation taken place. Moreover, reductions in the element contents of these samples might pass unnoticed if they are small, or appear less relevant than they truly are.

\section{Conclusions}

Iris pseudacorus shows a great capacity to tolerate and accumulate both $\mathrm{Zn}$ and $\mathrm{Cr}$, which displayed distinct distribution patterns, thereby leading to specific physiological responses. Chromium was retained mainly in roots, causing greater root damage than $\mathrm{Zn}$. Zinc was partially exported to the rest of the plant, and consequently caused a higher decrease in the growth of photosynthetic tissues, but less root malfunction. The functionality of the PSII persisted in all the treatments, and the stomatal aperture was only partially limited by $\mathrm{Cr}$.

We conclude that the reduction of growth in I. pseudacorus in response to exposure to $\mathrm{Cr}$ and $\mathrm{Zn}$ is due to the restricted mineral and water uptake and to the increased demand of carbohydrates of damaged roots, rather than to the direct effects of these metals on photoassimilating tissues. Biomass allocation to rhizomes $(\mathrm{Cr})$ or roots $(\mathrm{Zn})$ may contribute to heavy metal tolerance in this species by reducing transpiration and increasing metal-accumulating tissues and/or the surface for water and mineral uptake.

The high biomass production and metal extraction capacity makes this species a good candidate for $\mathrm{Cr}$ rhizofiltration and $\mathrm{Zn}$ phytoextraction, as reflected by the level of exportation of each metal to leaves. The reduced exportation of $\mathrm{Cr}$ to leaves can be advantageous for flower production, yield of emerged parts, and human safety. Metal extraction would also be higher than in environments polluted by $\mathrm{Zn}$, as long as the whole plant is collected. After harvest the metal-enriched biomass must be disposed 
of safely, a technical issue which remains partially unsolved. A variety of techniques under development, i.e. composting, compacting, pyrolysis, or biogas production (Ghosh and Singh 2005; Rai 2009), will remove this limitation in future and allow for a wider use of phytoremediation.

Author contribution C. Caldelas designed and performed the experiments, obtained the analytical data, interpreted the results and wrote the manuscript. J.L. Araus, J. Bort and A. Febrero, acting as thesis advisors, supervised the conception and development of the experiments, discussed the interpretation of the results, and reviewed the proofs of the manuscript.

Acknowledgments This study was part of the International Cooperation European Project MEDINDUS, EC Contract No INCO-CT2004-509159. Experiments were conducted in the experimental field services (Servei de Camps Experimentals) of the Universitat de Barcelona. Sample digestion and determination of element content were performed in the technical services (Serveis Científicotècnics) of the Universitat de Barcelona. We wish to thank their personnel for their collaboration and advice.

\section{References}

Ali NA, Dewez D, Didur O, Popovic R (2006) Inhibition of photosystem II photochemistry by $\mathrm{Cr}$ is caused by the alteration of both D1 protein and oxygen evolving complex. Photosynth Res 89:81-87. doi:10.1007/s11120-006-9085-5

Baker AJM, Brooks RR (1989) Terrestrial higher plants which hyperaccumulate metallic elements-a review of their distribution, ecology and phytochemistry. Biorecovery 1:81-126

Bakker RR, Elbersen HW (2005) Managing ash content and quality in herbaceous biomass: an analysis from plant to product. In: 14th European biomass conference and exhibition, 17-21 October 2005, Paris, France

Belmont MA, Metcalfe CD (2003) Feasibility of using ornamental plants (Zantedeschia aethiopica) in subsurface flow treatment wetlands to remove nitrogen, chemical oxygen demand and nonylphenol ethoxylate surfactants-a laboratory-scale study. Ecol Eng 21:233-247. doi:10.1016/j.ecoleng.2003.10.003

Bonet A, Poschenrieder C, Barceló J (1991) Chromium III - Iron Interaction in Fe-deficient and Fe-sufficient bean plants. 1. Growth and nutrient content. J Plant Nutr 14:403-414. doi: 10.1080/01904169109364211

Boutton TW, Archer SR, Milwood AJ, Zitzer SF, Bol R (1998) $\delta^{13} \mathrm{C}$ values of soil organic carbon and their use in documenting vegetation change in a subtropical savanna ecosystem. Geoderma 82:5-41. doi:10.1016/S0016-7061(97)00095-5

Broadley MR, White PJ, Hammond JP, Zelko I, Lux A (2007) Zinc in plants. New Phytol 173:677-702

Buchner P, Takahashi T, Hawkesford J (2004) Plant sulphate transporters: co-ordination of uptake, intracellular and longdistance transport. J Exp Bot 55:1765-1773. doi:10.1093/jxb/ erh206

Caldelas C, Bort J, Febrero A (2012) Ultrastructure and subcellular distribution of $\mathrm{Cr}$ in Iris pseudacorus L. using TEM and X-ray microanalysis. Cell Biol Toxicol 28:57-68. doi:10.1007/s10565011-9205-7
Chandra P, Kulshreshtha K (2004) Chromium accumulation and toxicity in aquatic vascular plants. Bot Rev 70:313-327. doi: 10.1663/0006-8101(2004)070[0313:CAATIA]2.0.CO;2

Chatterjee J, Chatterjee C (2000) Phytotoxicity of cobalt, chromium and copper in cauliflower. Environ Pollut 109:69-74. doi: 10.1016/S0269-7491(99)00238-9

Deng H, Ye ZH, Wong MH (2006) Lead and zinc accumulation and tolerance in populations of six wetland plants. Environ Pollut 141:69-80. doi:10.1016/j.envpol.2005.08.015

Dhir B, Sharmila P, Pardha Saradhi P (2008) Photosynthetic performance of Salvinia natans exposed to chromium and zinc rich wastewater. Braz J Plant Physiol 20:61-70. doi:10.1590/ S1677-04202008000100007

Farquhar GD (1983) On the nature of isotope discrimination in C4 species. Aust J Plant Physiol 9:205-226. doi:10.1146/annurev. pp.40.060189.002443

Genty B, Briantais JM, Baker NR (1989) The relationship between the quantum yield of photosynthetic electron transport and quenching of chlorophyll fluorescence. Biochim Biophys Acta 990:87-92. doi:10.1016/S0304-4165(89)80016-9

Ghosh M, Singh SP (2005) A review on phytoremediation of heavy metals and utilization of its byproducts. Appl Ecol Environ Res 3:1-18

Han Y, Yuan H, Huang S, Guo Z, Xia B, Gu J (2007) Cadmium tolerance and accumulation by two species of Iris. Ecotoxicol 16:557-563. doi:10.1007/s10646-007-0162-0

Hara T, Sonoda Y (1979) Comparison of the toxicity of heavy metals to cabbage growth. Plant Soil 51:127-133

Hermans C, Hammond JP, White PJ, Verbruggen N (2006) How do plants respond to nutrient shortage by biomass allocation? Trends Plant Sci 11:610-615. doi:10.1016/j.tplants.2006.10.007

Janik E, Maksymiec W, Mazur R, Garstka M, Gruszecki WI (2010) Structural and functional modifications of the major light-harvesting complex II in cadmium- or copper-treated Secale cereale. Plant Cell Physiol 51:1330-1340. doi:10.1093/pcp/pcq093

Krall JP, Edwards G (1992) Relationship between photosystem II activity and $\mathrm{CO}_{2}$ fixation in leaves. Physiol Plant 86:180-187. doi:10.1111/j.1399-3054.1992.tb01328.x

Krugh B, Bischham L, Miles D (1994) The solid-state chlorophyll meter, a novel instrument for rapidly and accurately determining the chlorophyll concentration in seedling leaves. Maize Genet Coop News Lett 68:25-27

Küpper H, Küpper F, Spiller M (1996) Environmental relevance of heavy metal-substituted chlorophylls using the example of water plants. J Exp Bot 47:259-266

Kuzovkina YA, Quigley MF (2005) Willow beyond wetlands: uses of Salix L. species for environmental projects. Water Air Soil Pollut 162:183-204. doi:10.1016/j.ecoleng.2009.03.010

Larue C, Korboulewsky N, Wang RY, Mévy JP (2010) Depollution potential of three macrophytes: exudated, wall-bound and intracellular peroxidase activities plus intracellular phenol concentrations. Bioresour Technol 101:7951-7957. doi:10.1016/j. biortech.2010.05.010

Lichtenthaler HK (1987) Chlorophylls and carotenoids: pigments of photosynthetic biomembranes. Methods Enzymol 148: $350-382$

Malik A (2007) Environmental challenge vis a vis opportunity: the case of water hyacinth. Environ Int 33:122-138. doi:10.1016/j. envint.2006.08.004

Manceau A, Nagy KL, Marcus MA, Lanson M, Geoffroy N, Jacquet T, Kirpichtchikova T (2008) Formation of metallic copper nanoparticles at the soil-root interface. Environ Sci Technol 42:1766-1772. doi:10.1021/es072017o

Marschner H (1995) Mineral nutrition of higher plants. Academic Press, London 
Maxwell K, Johnson GN (2000) Chlorophyll fluorescence-a practical guide. J Exp Bot 51:659-668. doi:10.1093/jexbot/ 51.345.659

Mazej Z, Germ M (2009) Trace element accumulation and distribution in four aquatic macrophytes. Chemosphere 74:642-647. doi: 10.1016/j.chemosphere.2008.10.019

Oláh V, Lakatos G, Bertók C, Kanalas P, Szőllősi E, Kis J, Mészáros I (2010) Short-term chromium (VI) stress induces different photosynthetic responses in two duckweed species, Lemna gibba L. and Lemna minor L. Photosynthetica 48:513-520. doi: 10.1007/s11099-010-0068-6

Paiva L, Oliveira J, Azevedo R, Ribeiro D, Silva M, Vitoria A (2009) Ecophysiological responses of water hyacinth exposed to $\mathrm{Cr}^{3+}$ and $\mathrm{Cr}^{6+}$. Environ Exp Bot 65:403-409. doi:10.1016/j.envexpbot. 2008.11.012

Pavlovič A, Masarovičová E, Král’ová K, Kubová J (2006) Response of chamomile plants (Matricaria recutita L.) to cadmium treatment. Bull Environ Contam Toxicol 77:763-771. doi: 10.1007/s00128-006-1129-1

Polyák K, Hlavay J (1999) Environmental mobility of trace metals in sediments collected in the Lake Balaton. Fresenius $\mathbf{J}$ Anal Chem 363:587-593

Prasad MNV (2004) Heavy metal stress in plants. From biomolecules to ecosystems. Springer, Berlin

Prasad DDK, Prasad ARK (1987) Altered delta-aminolevulinic-acid metabolism by lead and mercury in germinating seedlings of bajra (Pennisetum typhoideum). J Plant Phys 127:241-249

Prasad MNV, Strzałka K (2002) Physiology and biochemistry of metal toxicity and tolerance in plants. Kluwer, Dordrecht

Price AH, Steele KA, Gorham J, Bridges JM, Moore BJ, Evans JL, Richardson P, Jones RGW (2002) Upland rice grown in soilfilled chambers and exposed to contrasting water-deficit regimes. I. Root distribution, water use and plant water status. Field Crops Res 76:11-24. doi:10.1016/S0378-4290(02)00012-6

Qian JH, Zayed A, Zhu YL, Yu M, Terry N (1999) Phytoaccumulation of trace elements by wetland plants: III. Uptake and accumulation of ten trace elements by twelve plant species. J Environ Qual 28:1448-1455

Qiu S, Huang S (2008) Study on growth and Cd accumulation of root system of Iris pseudacorus seedling under Cd stress. J Plant Res Environ 17:33-38. doi:CNKI:SUN:ZWZY.0.2008-03-007

Rai PK (2009) Heavy metal phytoremediation from aquatic ecosystems with special reference to macrophytes. Crit Rev Environ Sci Technol 39:697-753. doi:10.1080/10643380801910058

Romanowska E, Igamberdiev AU, Parys E, Gardestrom P (2002) Stimulation of respiration by $\mathrm{Pb}^{2+}$ in detached leaves and mitochondria of C-3 and C-4 plants. Physiol Plant 116:148-154. doi:10.1034/j.1399-3054.2002.1160203.x

Salt DE, Smith RD, Raskin I (1998) Phytoremediation. Annu Rev Plant Physiol Plant Mol Biol 49:643-648

Samecka-Cymerman A, Kempers AJ (2001) Concentrations of heavy metals and plant nutrients in water, sediments and aquatic macrophytes of anthropogenic lakes (former open cut brown coal mines) differing in stage of acidification. Sci Total Environ 281:87-98. doi:10.1016/S0048-9697(01)00838-5

Shanker AK, Cervantes C, Loza-Tavera H, Avudainayagem S (2005) Chromium toxicity in plants. Environ Int 31:739-753. doi: 10.1016/j.envint.2005.02.003

Skeffington RA, Shewry PR, Peterson PJ (1976) Chromium uptake and transport in barley seedlings (Hordeum vulgare L.). Planta 132:209-320

Stobrawa K, Lorenc-Plucińska G (2007) Changes in carbohydrate metabolism in fine roots of the native European black poplar (Populus nigra L.) in a heavy-metal-polluted environment. Sci Total Environ 373:157-165. doi:10.1016/j.scitotenv.2006.11.019

Todeschini V, Lingua G, D’Agostino G, Carniato F, Roccotiello E, Berta G (2011) Effects of high zinc concentration on poplar leaves: a morphological and biochemical study. Env Exp Bot 71:50-56. doi:10.1016/j.envexpbot.2010.10.018

USEPA (2005) Priority pollutants. Code of federal regulations. Title 40: protection of environment, chap I. Appendix A to 40 CFR Part 423. 1st July 2005. Environmental Protection Agency

Uveges JL, Corbett AL, Mal TK (2002) Effects of lead contamination on the growth of Lythrum salicaria (purple loosestrife). Environ Pollut 120:319-323. doi:10.1016/S0269-7491(02)00144-6

Vernay P, Gauthier-Moussard C, Hitmi A (2007) Interaction of bioaccumulation of heavy metal chromium with water relation, mineral nutrition and photosynthesis in developed leaves of Lolium perenne L. Chemosphere 68:1563-1575. doi:10.1016/j.chemo sphere.2007.02.052

Wei L, Yan C, Wu G, Guo X, Ye B (2008) Variation of $\delta^{13}$ C in Aegiceras corniculatum seedling induced by cadmium application. Ecotoxicol 17:480-484. doi:10.1007/s10646-008-0201-5

Zhang X, Liu P, Yang Y, Chen W (2007) Phytoremediation of urban wastewater by model wetlands with ornamental hydrophytes. J Environ Sci 19:902-909

Zhou YQ, Huang SZ, Yu SL, Gu JG, Zhao JZ, Han YL, Fu JJ (2010) The physiological response and sub-cellular localization of lead and cadmium in Iris pseudacorus L. Ecotoxicol 19:69-76. doi: 10.1007/s10646-009-0389-z 